УДК 34.03

DOI https://doi.org/10.32849/2663-5313/2020.4.44

Анастасія Чемодурова,

студентка факультету адвокатури

Національного юридичного університету імені Ярослава Мудрого

\title{
ПРАВОВЕ РЕГУЛЮВАННЯ ТА ЙОГО ЕФЕКТИВНІСТЬ У СУЧАСНОМУ СВІТІ
}

Стаття присвячена розгляду теоретичного аспекту правового регулювання, визначенню ивого поняття шляхом аналізу поглядів інших науковців. Висвітлено питання способів, засобів $і$ методів його закріплення. Розглянуто цінність, иілі та сферу правового регулювання загалом. Також звернено увагу на таку проблему, як доречність меж, установлених державою та правом, і їхню відповідність сучасним умовам життя. Аналізується важливість правильного врегулювання суспільних відносин за допомогою встановлення норм, потрібних на съогодні.

Неоднорідність соиіуму в усі часи потребувала розумного й чіткого врегулювання шляхом установлення певних меж і їх правового закріплення. Систематизація правил поведінки йланок суспільних відносин здійснюється за допомогою механізму правового регулювання. У статті визначено, які саме складові иього механізму: способи (дозволяння, зобов'язування, заборона), типи (загальнодозволений і спеціально дозволений) і методи (диспозитивний, імперативний, рекомендаиійний, заохочувальний). За допомогою варіацій поєднання цих засобів установлюються межі поведінки людей. Однак постає проблема невідповідності закріплених кордонів сучасним вимогам суспільства. В статті висвітлюються актуальні факти розширення певних прав людини в багатьох країнах.

Не позбавлено актуальності також питання визначення рівня ефективності правового регулювання сьогодні шляхом аналізу його засобів. Автором розглянуто чинники, що впливають на дієвість правового регулювання в країні, та принципи ефективності. Визначивии критерії оцінювання (иінність, ефективність й економність) результативності правового регулювання, автор проаналізував ефективність правового регулювання сучасної України. Актуалізується проблема низького рівня правосвідомості населення й фактичної відсутності правового виховання громадян. Зазначено основні неврегульовані ланки суспільних відносин і нагальні проблеми, які залишаються невирішеними. Наприклад, невідповідність доходів осіб і витрат на проживання, корупчія, екологічна проблема. Підсумовується, що стосовно цих і багатьох інших аспектів людського життя механізм правового регулювання діє неефективно й не має чітких установлених норм і правил.

Ключові слова: правове регулювання, право, межі, способи, ефективність правового регулювання.

Постановка проблеми. Серед структурних елементів правової системи важливе місце належить правовому регулюванню. Встановлення необхідних правил і норм, що створюють кордони дозволеної поведінки для кожної особи, задля безпеки й спокою в суспільстві було й залишається одним з найважливіших аспектів для дослідження науковцями та юристами. Однак актуальною проблемою сьогодні $€$ виваженість і правильність меж, закріплених у нормативно-правових актах, що врегульовують суспільні відносини в XXI ст. Засоби правового регулювання є об'єктом досліджень науковців, адже від їхньої роботи й дієвості залежить ефективність правового регулювання. Невідповідність установлених граней інтересам та умовам життя населення впливає на показник результативності правового регулювання. Також існує багато важливих глобальних аспектів, які досі не врегульовані державою й правом. Відсутність систематизації нагальних питань має наслідком недовершеність правової системи, що може призвести до незадоволення та недовіри населення до влади.

Питанню правового регулювання та його ефективності приділяли увагу науковці всіх країн. Проблематику дієвості механізму правового регулювання досліджували такі фахівці, як М.В. Цвік, Л.С. Явіч, В.В. Лазарєв, С.С. Алексєєв, І.Я. Дюрягін, В.П. Корельський, В.М. Горшенєв, А.М. Вітченко, А.Ф.Черданцев, Ю.С. Решетов, В.І. Попов, П.М. Рабінович, А.С. Піголкін, Н.І. Козюбра, М.Ф. Орзіх, В.Б Ісаков, В.К. Самігулін, В.В. Копєйчиков, А.М. Колодій, С.Л. Лисенков, В.П. Пастухов, В.О. Сумін, О.Д. Тихомиров, О.Ф. Скакун та інші.

Метою статті $є$ дослідження теоретичних питань правового регулювання, способів, 
методів, типів його встановлення та аналіз ефективності нормативно-правового регулювання суспільних відносин у сучасному світі.

Виклад основного матеріалу. Суспільство - об'єднання людей, яке в усі часи було диференційованим і неоднорідним. Через різницю матеріального стану, духовного рівня розвитку осіб у соціумі, ставлення до певних речей виникають дискусії та спори між окремими особами, які іноді переходять межу й можуть набувати суспільно небезпечного статусу. Саме для встановлення цієї «межі» й існує інститут правового регулювання.

Для початку необхідно визначити значення терміну «правове регулювання». Існуе безліч варіантів тлумачення цього поняття Так, на думку А.М. Куліша, «правове регулювання - це здійснюваний в інтересах суспільства за допомогою норм права вплив на поведінку учасників суспільних відносин з метою встановлення й упорядкування останніх» [7, c. 62].

Дуже схожі визначення цього поняття дають В.В. Копєйчик та Г.О. Саміло. Автори підручника «Загальна теорія держави та права» за редакцією В.В. Копєйчикова під правовим регулюванням розуміють дію права на суспільні відносини за допомогою певних юридичних засобів, насамперед норм права [4, с. 217]. За Г.О. Саміло правове регулювання «це вплив права на суспільні відносини за допомогою спеціальних юридичних засобів, переважно норм права» [9, с. 273].

На думку Л.С. Явич, правове регулювання суспільних відносин здійснюється саме 3 моменту видання нормативно-правового акта [13]. Ширше визначення шляхом аналізу встановив Р.Я. Демків: ЮЮидичне регулювання визначається як специфічна діяльність держави, її органів, посадових осіб і уповноважених на те громадських організацій щодо впорядкування суспільних відносин шляхом установлення юридичних норм і прийняття в необхідних випадках індивідуальних рішень відповідно до цих норм, вирішення юридично значимих питань, що виникають у межах таких відносин» [3, с. 21].

Проаналізувавши думки науковців, хотілося б вивести власне визначення правового регулювання як упорядкування суспільних відносин державою шляхом установлення певних меж, закріплення норм і правил поведінки для осіб з метою забезпечення порядку й безпеки в суспільстві. Сферою правового регулювання є різні види відносин, наприклад економічні, політичні, духовнокультурні, національні, релігійні тощо, які вирізняються цілеспрямованістю, змістом і формою. Цілі правового регулювання стосу- ються не лише окремих суб'єктів, а й забезпечують закріплення та стимулювання розвитку суспільних відносин, створюють умови для виникнення нових суспільних відносин, запобігають виникненню суспільно шкідливих відносин [11, с. 83].

У XXI столітті, коли люди стали активнішими й обізнаними у своїх правах, обов'язках, свободах, поширюються рухи для встановлення ширших граней для кожної особистості або групи осіб. В основному люди вимагають забезпечення їхніх власних прав, виконання обов'язків чиновниками й депутатами, збалансування зарплатні та суми податків, одним словом задоволення звичайної потреби в комфортному житті. Але завжди є такі, що мають на меті глобальні зміни, розширення кордонів стосовно прав суспільства або певних груп населення, встановлених правом. Тож виникає питання: наскільки доречні ті межі, встановлені державою й правом для суспільства сьогодні, та наскільки ефективно вони діють?

Завдяки механізму правового регулювання, сукупності способів (дозволяння, зобов'язання, заборона), методів (диспозитивний, імперативний, рекомендаційний, заохочувальний) і засобів дотримання вимог правового регулювання встановлюється певний обсяг прав осіб, нормами права закріплюються зобов'язання й заборони для забезпечення рівності й справедливості членів соціуму. Однак межі, встановлені державою й правом, сьогодні не відповідають вимогам населення, яке вже має високий рівень правосвідомості й бажає домогтися розширення прав відповідно до сучасних умов життя.

У багатьох країнах з високим рівнем розвитку влада йде на поступки населенню й відповідно до реалій змінює законодавчо закріплені норми права, що регулюють суспільні відносини. Так, наприклад, у деяких країнах офіційно дозволені одностатеві шлюби (близько 30 країн) або ж частково дозволено використання певних наркотичних засобів як медичного засобу (у 8 країнах). Звісно, розширення певних прав відбувається з огляду на менталітет країни та їі моральні установки. Існує безліч рухів за зміни в обсязі певних прав і свобод людей у бік їх розширення, в основному для забезпечення вищого рівня життя населення й зменшення кількості обов'язків, або їх пристосування до сучасних умов. Невідповідність бажаного життя й реального призводить до апатії й недовіри до права й політики, що проявляється в неправомірній поведінці. Неправомірна поведінка може бути небезпечною для окремих осіб або суспільства загалом. 
Соціум є неоднорідним і вимагає встановлення порядку, що забезпечить свободу, справедливість і впевненість у власній захищеності кожному члену об'єднання. Для цього й створено механізм правового регулювання з усіма його методами та способами встановлення меж й одночасно підтримання свободи особистості. Насамперед воно діє як система, що структурує правила поведінки, створює умови для правомірного співіснування осіб у суспільстві.

Слід звернути увагу на те, що з часом межі, встановлені правом і державою в суспільстві, змінюються й рухаються в бік звуження або, навпаки, збільшення обсягу певних прав і свобод, задовольняючи вимоги окремих особистостей або груп індивідів. Зміни окремих правил і меж обумовлені розвитком самосвідомості осіб і соціуму в цілому, що $€$ проявом еволюції особистості. Отже, можна зробити висновок, що в зрушенні меж, установлених правом, суспільством, державою, немає нічого надзвичайного. Змінюються люди, вимагають змін стосовно своїх прав, обов’язків і свобод. Але, якщо поглянути на ситуацію з іншого боку, суспільство стає менш керованим державою, руйнує деякі кордони, щоб стати вільнішим, самостійним, незалежним. Правове регулювання створене як для забезпечення прав людей і гарантії їх дотримання, так і для встановлення обмежень для громадян з метою уникнення хаосу. Виникає питання: чи не призведе така жага до розширення своїх свобод і прав, зменшення обов'язків, що все частіше прослідковується в таких діях, як паради або демонстрації, до неконтрольованості суспільства? Адже, наприклад, мітинг у демократичній країні можна завершити, лише задовольнивши певні умови тієї групи осіб, що вчинила спротив, тобто знову змінити певні встановлені грані. Де ж та межа змін?

У кожній демократичній державі закріплені природні права й свободи людини, такі як право на життя, відпочинок, свобода слова, думки, віросповідання та інші. Вони $\epsilon$ невіддільними й забезпечуються та гарантуються державою. Отже, найважливішим, що має бути врегульовано й захищено державою без змін, є природні права людини та іï свободи. Але існують ситуації, коли особи користуються й зловживають своїми правами, що проявляється в агресивному доведенні своєї правоти, коли людина не має розуміння самої норми права.

Одним із засобів координації таких випадків є способи правового регулювання. Способи правового регулювання це такі складові елементи впорядкованих суспільних відносин: дозволяння, зобов’язування (веління), заборона [10, с. 496]. Вони визначають можливості й межі для людей у певних аспектах соціального життя. Усі способи правового регулювання потребують юридичного оформлення й закріплення в правових актах.

Розглянемо кожен спосіб окремо для глибшого розуміння їхньої сутності та функцій. Юридичне дозволяння означає визнання за особою суб'єктивного права здійснити певні юридично значущі дії або утриматися від них, вільно обрати варіант власної поведінки. Особа обирає один із передбачених дозволянням варіантів поведінки виключно самостійно, без зовнішнього примушування [12, с. 138]. Функції способу дозволяння: забезпечення соціальної свободи людини, надання варіативності рішень, забезпечення вільного вибору використання способу особистістю (діяння або бездіяльність). Проте слід пам'ятати, що будь-яке юридичне дозволяння має межі дозволеного, які визначаються суспільною безпекою, правами інших осіб, принципами права (гуманність, справедливість, рівність, свобода), здоровим глуздом та іншими чинниками.

Другий спосіб - зобов'язування. Зобов'язування виявляється в покладенні на учасників регламентованих правом суспільних відносин суб'єктивного юридичного обов'язку активного типу, що спонукає його носіїв до дій, передбачених правовими нормами [5, с. 214]. На відміну від дозволяння, спосіб зобов'язування обтяжує особу, тому що вимагає активних дій, а не надає вибір між діянням і бездіяльністю. Воно передбачає дотримання певних правил, обов'язків діяти так, як прописано в певному нормативно-правовому акті, не зважаючи на бажання особи. Сутність юридичного зобов'язування полягає у вимозі необхідної, потрібної, корисної й доцільної з точки зору права активної поведінки особи. Ця поведінка $є$ обов'язковою, забезпеченою державним примусом [12, с. 139]. Основною функцією цього способу є встановлення меж дозволеного шляхом установлення обов'язку в певних ситуаціях діяти так, як визначено в нормах права.

Останній основний спосіб правового регулювання, який ми розглянемо, - спосіб заборони. Юридична заборона встановлюється шляхом покладення на особу юридичного обов'язку пасивного типу, відповідно до чого вона має утримуватися від певних юридично значущих дій $[6$, с. 99]. Сутність юридичної заборони полягає у вимозі пасивної поведінки особи, а саме утриматися від певної соціально шкідливої поведінки під загрозою настання юридичної відповідальності для порушника цієї заборони. 
Норми особливої частини Кримінального кодексу $є$ фактично заборонами, оскільки вони встановлюють відповідальність за певні дії й тим самим їх забороняють [10, с. 496]. Така поведінка не виключається й залишається можливою, але є юридично забороненою. Основним завданням юридичних заборон є захист й охорона права. Зобов'язування (веління) й заборони превалюють в основному в галузях, що належать до публічного права.

Також існують допоміжні способи правового регулювання: примус, заохочення, надання пільг, рекомендації, покарання (не мають самостійного інструментального значення й застосовуються разом з основними способами правового регулювання для посилення або оптимізації їхньої дії) [2, с. 279].

Усі способи правового регулювання обумовлені функціями права: регулятивнодинамічною - дозвіл і зобов'язання; регулятивно-статичною - заборона [1, с. 106]. Способи правового регулювання (дозволяння, зобов'язування, заборона) 3 більшою ефективністю досягають своєї мети лише за умови тісного взаємозв'язку один з одним. Дозволяння особі певної поведінки буде реальним за наявності обов'язку в інших осіб задовольнити потреби, що виникли у цьому зв'язку в правомочної особи. Тобто для забезпечення роботи одного способу необхідно забезпечити працездатність інших способів у суспільстві в цілому й для кожного індивіда окремо.

Ще одним не менш важливим критерієм є тип правового регулювання. Комбінації способів правового регулювання характеризують певну спрямованість впливу права на суспільні відносини, визначають типи правового регулювання (загальнодозволений, спеціально дозволений) [6, с. 99].

Призначення правового регулювання полягає в приведенні в дію необхідних елементів правової системи, забезпеченні іх «роботи» для задоволення законних прав й інтересів суб' єктів права. Усі складові механізму правового регулювання, що допомагають здійснювати впорядкування суспільних відносин, мають приводити до певного результату, досягати мети правового регулювання. Однак держава повинна робити аналіз актуальності й дієвості правового регулювання, а в разі невідповідності сучасним умовам здійснювати реформи й удосконалювати цей механізм. Результативність і соціальна значущість правового регулювання визначаються його ефективністю, тобто спроможністю правового регулювання приводити до максимально можливих позитивних результатів шляхом застосування обгрунтованих, розумних і доцільних витрат й обмежень.
Існують певні усталені принципи правового регулювання, дотримання яких обумовлює його ефективність. Найважливішими з них є доцільність, адекватність, збалансованість, передбачуваність, прозорість і врахування громадської думки. Дотримання вказаних принципів не єдиний i далеко не головний чинник, що впливає на дієвість регулювання суспільних відносин. Від чого ж ще залежить ефективність правового регулювання?

Науковці висловлюють різні думки стосовно чинників, від яких залежить ефективність правового регулювання, однак деякі висновки збігаються. Так, найбільше на дієвість правового регулювання впливають такі чинники:

1) досконалість нормативної основи правового регулювання (відповідність юридичних норм загальносоціальним закономірностям і природі суспільних відносин, наявність відпрацьованих процедурних механізмів реалізації норм матеріального права, своєчасність оновлення законодавства; дотримання під час підготовки нормативно-правових актів правил законодавчої техніки, яка забезпечує прийняття логічних за побудовою й доступних за змістом нормативних правових документів);

2) стан юридичної практики на рівні правозастосування (якість підготовки й наявність стимулів для продуктивної праці фахівців, які здійснюють правозастосовчу діяльність; узгодженість дій різних юридичних установ; матеріальна оснащеність юридичних установ);

3) соціально-правові передумови правового регулювання (наявність у суспільстві режиму законності; ступінь відповідності інтересів і потреб учасників суспільних відносин, що піддаються правовій регламентації, іiї цілям; стан правової інформованості цих осіб; узгодженість між собою систем правової й моральної регуляції соціальної поведінки; рівень розвитку правової культури учасників суспільних відносин) [2, с. 285];

4) відповідність юридичної норми стану правосвідомості й моралі, рівню загальної культури, громадській думці суб'єктів;

5) відповідність норм реальним потребам та інтересам тих суб'єктів, відносини між якими вона має регулювати, відображати й враховувати [8, с. 173].

Можна зробити висновок, що ефективність правового регулювання залежить передусім від досконалості самої юридичної норми, процедурно-процесуального механізму її реалізації, діяльності з її застосування й реалізації, а також необхідності врегулювання певного аспекту суспільного життя. 
Щоб проаналізувати рівень дієвості правового регулювання необхідно визначити критерії оцінювання. Якість правового впливу на суспільні відносини відображають цінність, ефективність й економність правового регулювання.

Цінність правового регулювання характеризується позитивним впливом на існування й розвиток особи, створенням кращих умов для суспільства, групи осіб або окремої особистості. Економність визначається шляхом врахування витрат (предметно-речових, грошових, часових, кадрових, фізично-людських та інших), пов'язаних з досягненням певного результату правового регулювання. Останній критерій дієвості правового регулювання - ефективність, яка визначається порівнянням отриманого результату й початкової мети.

\section{Висновки}

Проаналізувавши критерії оцінювання ефективності правового регулювання, можна зробити висновок щодо дієвості правового регулювання в Україні сьогодні. Основні питання, які викликають незадоволення й протести українців, - диференціація населення за майновою ознакою, несправедливість, що проявляється в корупції й бюрократії, бідність більшості українців. До цих актуальних проблем долучається ще й глобальна екологічна проблема. Зазначені аспекти суспільних відносин потребують негайного й доречного правового врегулювання, проте наразі влада займається другорядними, неактуальними питаннями й установлює норми, що тільки ускладнюють умови життя людей. Неефективність правового регулювання обумовлена недосконалістю правової системи, прогалинами в законодавстві, невідповідністю норм реальним потребам й інтересам суб'єктів. Неврегульованість важливих ланок суспільного життя, наприклад недостатнього економічного забезпечення працюючого населення у вигляді низької зарплатні в порівнянні з сучасними цінами й сумою податків, може призвести до порушення заборон, установлених нормами права. Тобто наслідком недосконалого правового регулювання може бути неправомірна поведінка суб'єктів. На сьогодні система правового регулювання в Україні не $є$ довершеною, що проявляється насамперед у невідповідності норм права, встановлених державою, реальним умовам суспільного життя й інтересам населення й у низькому ступені наближення до всіх цілей, що ставилися під час здійснення правового регулювання. Не меншою неврегульованою проблемою залишається фактична відсутність системи правового виховання українців, що має певні наслідки. На жаль, нагальні й глобальні питання чомусь розглядаються вже тоді, коли перестають бути актуальними. Для забезпечення ефективності правового регулювання має значення його поетапний аналіз, що дає змогу з'ясувати, які саме ланки механізму правового регулювання неповною мірою виконують своє призначення, й усунути в подальшому ці недоліки.

\section{Список використаної літератури:}

1. Волинка К.Г. Теорія держави i права: навчальний посібник. Київ : МАУП, 2003. С. $229-232$.

2. Гладкий С.О. Теорія держави і права : навчально-методичний посібник. Полтава : ПУЕТ, 2016. 371 c.

3. Демків Р.Я. Правове регулювання як юридичне явище: окремі аспекти розуміння. Науковий вісник Ужгородського начіонального університету. Серія «Право». 2015. Вип. 34. Т. 1. С. 19-23.

4. Загальна теорія держави і права / за ред. В.В. Копєйчикова. Київ : Юрінком, 1997. 320 с

5. Загальна теорія держави і права : підручник для студентів / М.В. Цвік та ін. ; за ред. М.В. Цвіка, О.В. Петришина. Харків : Право, $2009.584 \mathrm{c}$.

6. Загальна теорія права : підручник / за заг. ред. М.І. Козюбри. Київ : Ваіте, 2015. 392 с

7. Куліш А.М. Організаційно-правове забезпечення статусу працівників податкової міліції України : дис. ... канд. юр. наук : спец. 12.00.07 / А.М. Куліш. Харків, 2003. 177 с.

8. Рабінович П.М. Основи загальної теорії права та держави : навчальний посібник. Львів : Край, 2007. 192 с.

9. Саміло Г.О. Теорія держави і права : навчальний посібник. Запоріжжя : Просвіта, 2010.348 c.

10. Скакун О.Ф. Теорія держави і права : підручник / пер. з рос. Харків : Консум, 2001. 656 с.

11. Тарахович T.I. Ефективність правового регулювання. Наукові записки. Серія «Юридичні науки». 2004. Т. 26. С. $82-84$

12. Теорія держави і права : підручник для студентів / О.В. Петришин та ін. ; за ред. О.В. Петришина. Харків : Право, 2015. 368 с.

13. Явич Л.С. Советское право - регулятор общественных отношений в СССР : автореф. дис. ... д-ра юрид. наук : 12.00.01. Ленинград, 1960. С. 18. 
The article deals with the theoretical aspect of legal regulation, the definition of this concept by analyzing the viewes of different scientists. The ways means and methods of its assimilation are covered. The significance, goals and the sphere of legal regulation in general are considered in the article. Much attention is paid to such problem as the relevance of the limits established by the state and the law and their conformity with the current living conditions. The importance of the correct regulation of social relations by establishing the currently required norms is analyzed.

At all times the heterogeneity of society required clear and strict regulation by setting certain limits and their legal confirmation. Systematization of behavior rules and aspects of social relations is carried out by using the mechanism of legal regulation. The article describes the components of this mechanism: means (allowability, obligation and prohibition), types (general and special-permitted) and methods of legal regulation (non-mandatory, mandatory, recommendatory and incentive). By means of combining these means, the limits of the behavior of individuals are set. However, there is a problem of inconsistency of fixed limits with current society requirements. As a result, the article highlights the current facts about the extending certain human rights in many countries.

The question of determining the level of effectiveness of legal regulation based on the analysis of its means is currently important. The author considers the factors that influence on the legal regulation efficiency in the country and the principles of its effectiveness. Having defined the evaluation criteria of the legal regulation efficiency (importance, efficiency and economy), the author analyzed the effectiveness of legal regulation in Ukraine nowadays. The problem of low level of public awareness and actual lack of citizens' legal education is actualized. The main unsettled aspects of public relations and urgent problems that remain unresolved are outlined. For example, the inconsistency of people's income and living expenses, the corruption and ecological problems. It is concluded that, due to these and many other aspects of human life, the legal regulation mechanism is ineffective and does not have clear norms and rules.

Key words: legal regulation, law, limits, means, effectiveness of legal regulation. 